\title{
ДІАГНОСТИКА СФОРМОВАНОСТІ ДОСЛІДНИЦЬКОЇ КОМПЕТЕНТНОСТІ МАЙБУТНІХ ТОВАРОЗНАВЦІВ-ЕКСПЕРТІВ
}

\author{
Діденко С. П., аспірант \\ Украӥна, м. Полтава, \\ Полтавський національний педагогічний університет ім. В. Г. Короленка, \\ аспірант кафедри хімії та методики викладання хімі
}

DOI: https://doi.org/10.31435/rsglobal_ws/30082018/6076

\section{ARTICLE INFO}

Received: 20 July 2018

Accepted: 19 August 2018

Published: 30 August 2018

\section{KEYWORDS}

research competence, future commodity-experts, chemical disciplines.

\begin{abstract}
In the article features are considered and the analysis of practical experience of professional training of future commodity experts. The problem of forming the research competence of future commodity experts in the process of studying chemical disciplines is outlined. Taking into account modern requirements of the labor market and social order, considerable attention is paid in the article to the formation of students of research qualities. It is proved that the involvement of future commodity experts in the research activity is a prerequisite for the formation of their research competence. A set of methods for diagnosing the level of formation of research competence of future commodity experts is proposed. Characterized by criteria and indicators by which the diagnostics of the formation of research competence of future commodity experts was conducted.

The results of estimation of the level of formation of research competence of future commodity experts by the application of the proposed diagnostic toolkit are highlighted. According to the obtained data, further research prospects and expected results are determined.
\end{abstract}

Citation: Діденко Є. П. (2018) Diahnostyka Sformovanosti Doslidnytskoi Kompetentnosti Maibutnikh Tovaroznavtsiv-Ekspertiv. World Science. 8(36), Vol.3. doi: 10.31435/rsglobal_ws/30082018/6076

Copyright: (C) 2018 Діденко С. П. This is an open-access article distributed under the terms of the Creative Commons Attribution License (CC BY). The use, distribution or reproduction in other forums is permitted, provided the original author(s) or licensor are credited and that the original publication in this journal is cited, in accordance with accepted academic practice. No use, distribution or reproduction is permitted which does not comply with these terms.

Introduction. Одним 3 основних завдань сучасної освіти України $є$ підготовка конкурентоспроможних фахівців 3 високим рівнем професійної підготовки та мотивації до ведення дослідницької діяльності, здатних до саморозвитку та самовдосконалення, мобільності та креативності. Національні освітні стандарти підготовки товарознавців-експертів більшою мірою націлені на формування у випускників компетентностей, необхідних для роботи в митних органах, не враховуючи те, що більшість фахівців будуть працювати товарознавцямиекспертами на виробництві, чи у секторі реалізації товарів народного споживання. Тому, на нашу думку, однією 3 основних професійних компетентностей майбутнього товарознавцяексперта є саме дослідницька.

На наш погляд, досить вагому роль у процесі формування дослідницької компетентності майбутніх товарознавців-експертів відіграє вивчення хімічних дисциплін, оскільки, саме оволодіння теоретичними хімічними знаннями, уміннями проводити експериментальні дослідження з визначення якості товарів народного споживання є базою для формування дослідницької компетентності фахівців даного профілю.

На нашу думку, вирішення проблеми підготовки майбутніх товарознавців-експертів зі сформованою дослідницькою компетентністю стане можливим за умови розвитку у них 
дослідницьких якостей починаючи з першого курсу навчання у вищій школі. Необхідність формування та розвитку дослідницьких умінь - це важлива складова у процесі фахової підготовки майбутніх товарознавців-експертів, а відтак і основа для здійснення дослідницької діяльності в контексті обраного фаху.

Research results. Перш, ніж розпочати діагностику сформованості дослідницької компетентності майбутніх товарознавців-експертів ми провели трирівневе анкетування до якого були залучені потенційні роботодавці, сфера діяльності яких пов’язана з виготовленням та реалізацією товарів народного споживання (47 осіб) Полтавської області, викладачі, які безпосередньо залучені до процесу фахової підготовки майбутніх товарознавців-експертів (34 особи) та студенти, що здобувають освіту за спеціальністю «Товарознавство та експертиза в митній справі» (260 осіб) у ВНЗ Укоопспілки «Полтавський університет економіки і торгівлі».

Респондентам пропонували відповісти на питання розроблених анкет. Опитування потенційних роботодавців показало, що процес фахової підготовки майбутніх товарознавцівекспертів слід поєднувати з розвитком та підтриманням на належному рівні у них мотивації до обраної професії (96 \%), залучати їх до ведення різнопланової дослідницької діяльності (87 \%), чим збагачувати практичний досвід ведення експериментальних досліджень.

Результати опитування викладачів свідчать про епізодичний характер залучення студентів до дослідницької діяльності (32\%) та переважаючий у масовій практиці досить низький рівень розвитку дослідницької компетентності майбутніх товарознавців-експертів (24%).

Відповіді майбутніх товарознавців-експертів підтвердили думку про те, що студенти недостатньо залучені до різнопланової дослідницької діяльності (45\%) і є необхідність в організації роботи (78\%), спрямованої на формування та удосконалення їх дослідницької компетентності саме у ході вивчення хімічних дисциплін.

Отримані дані підтверджують нашу думку про те, що у ході вивчення хімічних дисциплін майбутніх товарознавців-експертів слід залучати до виконання різнопланових науково-дослідницьких робіт, індивідуальних дослідницьких проектів, роботи проблемних груп, хімічних гуртків та студентських наукових об'єднань, що займаються дослідженнями у галузі визначення якості товарів народного споживання.

Відповідно обраної стратегії дослідження було визначено критерії та показники сформованості дослідницької компетентності майбутніх товарознавців-експертів, обрано дослідницькі методики для іiї діагностики.

Рівень сформованості дослідницької компетентності майбутніх товарознавців-експертів визначали за такими критеріями: мотиваційний, когнітивний, діяльнісний та рефлексійний. Вважаємо за доцільне конкретніше описати хід проведеної діагностики.

Мотиваційний критерій. Сформованість мотивів та потребу розвитку дослідницьких знань, умінь $і$ навичок майбутніх товарознавців-експертів діагностували за допомогою тесту визначення спрямованості на набуття знань С. Ільїна та Н. Курдякової [1]. Студентам запропонували дати відповіді на 12 питань анкети, за які нараховувалося від 0 до 12 балів. За кількістю отриманих балів визначили рівень сформованості мотивації майбутніх товарознавцівекспертів до формування дослідницьких знань, умінь і навичок: 1-4 бали - низький рівень, 5-8 балів - середній рівень, 9-12 балів - високий рівень.

Наявність стійкого інтересу, самостійності та творчого підходу при виконанні дослідницької діяльності визначали шляхом анкетування майбутніх товарознавців-експертів. Респондентам пропонували визначити своє відношення до представлених у бланку положень у балах (1 - повністю невірно, 2 - частково вірно і 3 - повністю вірно).

За результатами проведеного опитування майбутніх товарознавців-експертів визначили рівень сформованості стійкого інтересу, самостійності та творчого підходу при виконанні дослідницької діяльності: 1-26 балів - низький рівень, 27-52 - середній рівень, 53-78 - високий рівень.

Прагнення до самовдосконалення та підвищення рівня сформованості власної дослідницької компетентності визначали за методикою Ю. Орлова «Шкала оцінки потреби в досягненні» [3]. На запропоновані питання студенти давали позитивну, чи негативну відповідь. За кожне співпадіння з ключем студенту нараховувався 1 бал. У результаті аналізу відповідей респондентів визначили, що високий рівень сформованості третього показника мотиваційного критерію відповідає показнику 23-33 бали, середній - 12-22 бали, низький - 1-11 балів.

Сформованість показників когнітивного критерію дослідницької компетентності майбутніх товарознавців-експертів встановлюємо за повнотою засвоєних теоретичних знань. Визначення рівня сформованості когнітивного компоненту за виділеними показниками здійснювали шляхом застосування комплексу завдань, спрямованих на діагностику 
теоретичних знань майбутніх товарознавців-експертів стосовно пошуку, аналізу, синтезу інформації, необхідної у ході виконання дослідницької діяльності та розуміння структури власне дослідницького процесу. У ході виконання лабораторних робіт майбутнім товарознавцям-експертам пропонували завдання, виконання яких сприяло закріпленню теоретичних знань у сфері дослідницької діяльності, оволодіння методиками організації продуктивної дослідницької діяльності.

Упродовж навчального року здійснювали поточний контроль знань майбутніх товарознавців-експертів шляхом застосування самостійних робіт та тестування. Після вивчення студентами кожного змістовного блоку дисципліни проводилися контрольні роботи, котрі дозволили визначити рівень сформованості дослідницької компетентності.

Окрім того для визначення рівня сформованості когнітивного компоненту дослідницької компетентності майбутніх товарознавців-експертів брали до уваги результати заліково-екзаменаційної сесії з хімічних дисциплін.

Для цього вважаємо за доцільне визначити коефіцієнт повноти засвоєння необхідних знань за методикою поелементарного та поопераційного аналізу, розробленою А. Усовою [4]:

$$
K=\frac{\sum_{i=1}^{N} n_{i}}{N \cdot n},
$$

де $K$ - коефіцієнт ефективності виконання завдання, чи засвоєння навчального матеріалу;

$n_{i}$ - варіанта, що представляє кількість ознак, яку засвоїв $i$-тий студент, виконавши необхідні діï та операції;

$N$ - кількість студентів, залучених до процесу перевірки;

n-максимальна кількість понять, що підлягають засвоєнню на цьому етапі формування поняття;

Для визначення рівня сформованості виділених критеріїв когнітивного компоненту дослідницької компетентності майбутніх товарознавців-експертів проводимо кількісну обробку результатів діагностики, завдяки чому визначаємо коефіцієнт (кількісний показник) ступеня прояву кожного з них.

У нашому дослідженні використовуємо такі кількісні показники: високий рівень -3 бали $(0,9 \leq \mathrm{K} \leq 1)$, достатній -2 бали $(0,8 \leq \mathrm{K}<0,9)$, низький -1 бал $(0,8 \leq \mathrm{K}<0,9)$.

Показники діяльнісного критерію повноту оволодіння дослідницькою компетентністю та прагнення $i$ здатність до практичного використання дослідницьких компетенцій у ході розв'язання професійно-орієнтованих завдань визначаємо сукупністю отриманих балів за результати науково-дослідницьких проектів, успішне виконання яких обумовлювало використання майбутніми товарознавцями-експертами умінь пошуку необхідної інформації та iii продуктивного опрацювання, формулювання досліджуваної проблеми та категоріального апарату дослідження, планування перебігу дослідницького процесу, застосовування передових науково-дослідницьких методик, аналіз отриманих результатів дослідження та їх презентація.

Рівень оволодіння майбутніми товарознавцями-експертами дослідницькою компетентністю за діяльнісний критерієм за першими двома показниками визначаємо за кількістю балів, які студенти отримали після виконання власних науково-дослідницьких проектів: 15 - 11 балів - високий рівень, 6 - 10 балів - середній рівень, 5 - 0 балів - низький рівень.

Дослідження рівня сформованості дослідницької компетентності майбутніх товарознавців-експертів за третім показником діяльнісного критерію здійснювали за допомогою методики «Незакінчене рішення» [1].

Метою діагностики є встановлення наявності у майбутніх товарознавців-експертів бажання доводити почату справу до кінця, що слугує показником стійкого пізнавального інтересу, сили волі, креативності та прагнення до якісного вирішення професійно-орієнтованих завдань.

Відповідно методики, розрахунок результатів здійснюємо так: найвищі бали отримують студенти, хто завершили розв'язання завдання вдома, а також ті, хто почав шукати інші варіанти розв'язку (2 бали); студентам, які подовжили розв'язання після заняття, але кінцевої відповіді так і не отримали нараховують 1 бал; ті, хто не продовжили роботу над вирішенням завдання отримують 0 балів. За результатами застосування даної методики 0-1 бал співвідносимо з низьким рівнем сформованості досліджуваної якості майбутніх товарознавцівекспертів, 2 бали - середнім та 3 бали - високим, відповідно.

Усвідомлення важливості досліднищької діяльності з обраного фаху, що є першим показником рефлексійного критерію, досліджували за допомогою методики А. Карпова 
«Діагностика рефлексії» [2]. Студентам пропонували дати відповіді на 27 запитань, у результаті ïх аналізу було визначено рівні сформованості рефлексійності респондентів: до 113 балів низький рівень, 114-139 - достатній рівень, 140 і більше балів свідчить про високий рівень сформованості досліджуваної якості майбутніх товарознавців-експертів, який свідчить про здатність до аналізу власної дослідницької діяльності, ретельного планування та прогнозування з усіма можливими наслідками.

Визначення рівня готовності до здійснення досліднищької діяльності з обраного фаху здійснювали за допомогою переліку розроблених питань, у яких майбутнім товарознавцямекспертам було запропоновано проаналізувати й оцінити рівень сформованості власної рефлексійності, здатність до самоаналізу власної дослідницької діяльності.

Рівень сформованості у майбутніх товарознавців-експертів готовності до здійснення дослідницької діяльності з обраного фаху визначаємо за кількістю отриманих балів: 1-18 низький рівень, 19-36 - середній рівень, 37-54 - високий рівень.

Діагностику здатності до глибокого усвідомлення відповідальності за дї, щзо виконує майбутній товарознавець-експерт здійснювали за допомогою листа самооцінки дослідницької діяльності. Після завершення роботи над власним науково-дослідницьким проектом i презентацією результатів дослідження майбутнім товарознавцям-експертам пропонували самостійно оцінити результативність дослідницької діяльності. Студентам було запропоновано відповісти на питання, які висвітлювали рівень сформованості дослідницької компетентності, здатності до самоконтролю та усвідомлення відповідальності за результати власної професійної діяльності. Отримані відповіді порівняли з балами, які виставили експерти в листах оцінювання науково-дослідницьких проектів студентів. Високий рівень сформованості третього показника дослідницької компетентності за рефлексійним критерієм відповідає 11 - 15 отриманим балам, середній рівень - 6- 10 балів, низький рівень $-0-5$ балів.

Таблиця 1. Узагальнені результати показників сформованості дослідницької компетентності майбутніх товарознавців-експертів на початку дослідження.

\begin{tabular}{|c|c|c|c|c|c|c|}
\hline \multirow[t]{3}{*}{ Показники } & \multicolumn{6}{|c|}{ Рівні сформованості } \\
\hline & \multicolumn{2}{|c|}{ Високий } & \multicolumn{2}{|c|}{ Середній } & \multicolumn{2}{|c|}{ Низький } \\
\hline & осіб & $\%$ & осіб & $\%$ & осіб & $\%$ \\
\hline 1 & 2 & 3 & 4 & 5 & 6 & 7 \\
\hline \multicolumn{7}{|c|}{ Мотиваційний критерій } \\
\hline $\begin{array}{l}\text { Наявність мотивів і потреб у } \\
\text { розвитку дослідницьких знань, умінь } \\
\text { i навичок. }\end{array}$ & 36 & 13,85 & 153 & 58,85 & 71 & 27,3 \\
\hline $\begin{array}{l}\text { Наявність стійкого інтересу, } \\
\text { самостійності та творчого підходу } \\
\text { при виконанні дослідницької } \\
\text { діяльності. }\end{array}$ & 28 & 1077 & 120 & 46,15 & 112 & 43,08 \\
\hline $\begin{array}{l}\text { Прагнення до самовдосконалення та } \\
\text { підвищення рівня сформованості } \\
\text { власної дослідницької діяльності. }\end{array}$ & 60 & 23,07 & 176 & 67,7 & 24 & 9,23 \\
\hline \multicolumn{7}{|c|}{ Когнітивний критерій } \\
\hline $\begin{array}{l}\text { Інформативна обізнаність у сфері } \\
\text { дослідницької компетентності з } \\
\text { обраного фаху. }\end{array}$ & 54 & 20,77 & 158 & 60,77 & 48 & 18,46 \\
\hline $\begin{array}{l}\text { Розуміння структури дослідницького } \\
\text { процесу. }\end{array}$ & 31 & 11,9 & 119 & 45,78 & 110 & 42,31 \\
\hline $\begin{array}{l}\text { Знання способів і методик організації } \\
\text { продуктивної дослідницької } \\
\text { діяльності. }\end{array}$ & 18 & 6,92 & 75 & 28,85 & 167 & 64,23 \\
\hline
\end{tabular}


Продовження таблиці 1

\begin{tabular}{|c|c|c|c|c|c|c|}
\hline 1 & 2 & 3 & 4 & 5 & 6 & 7 \\
\hline \multicolumn{7}{|c|}{ Діяльнісний критерій } \\
\hline $\begin{array}{l}\text { Повнота оволодіння дослідницькою } \\
\text { компетентністю. }\end{array}$ & 44 & 16,921 & 83 & 31,92 & 133 & 51,16 \\
\hline $\begin{array}{l}\text { Прагнення та здатність до } \\
\text { практичного використання } \\
\text { дослідницької компетентності у ході } \\
\text { розв’язання професійно- } \\
\text { орієнтованих завдань. }\end{array}$ & 96 & 36,92 & 127 & 48,85 & 37 & 14,23 \\
\hline $\begin{array}{l}\text { Ступінь наполегливості, } \\
\text { відповідальності та креативності у } \\
\text { процесі виконання завдань } \\
\text { дослідницького характеру. }\end{array}$ & 78 & 30 & 148 & 56,92 & 34 & 13,08 \\
\hline \multicolumn{7}{|c|}{ Рефлексійний критерій } \\
\hline $\begin{array}{l}\text { Усвідомлення важливості } \\
\text { дослідницької діяльності з обраного } \\
\text { фаху. }\end{array}$ & 105 & 40,38 & 104 & 40 & 51 & 19,62 \\
\hline $\begin{array}{l}\text { Використання діагностично- } \\
\text { пошукових умінь у ході виконання } \\
\text { наукового дослідження. }\end{array}$ & 65 & 25 & 86 & 33,08 & 109 & 41,92 \\
\hline $\begin{array}{l}\text { Ступінь усвідомлення та осмислення } \\
\text { отриманих результатів. }\end{array}$ & 65 & 25 & 98 & 37,69 & 97 & 37,31 \\
\hline
\end{tabular}

Conclusions. Результати проведеного експерименту підтверджують інформацію про те, що сучасні умови професійної підготовки майбутніх товарознавців-експертів не забезпечують вимог роботодавців до рівня підготовки та професійної компетентності претендентів на роботу. Отримані результати свідчать, що майбутні товарознавці-експерти досить часто мають низький рівень розвитку дослідницької компетентності, не мають достатньої мотивації до ведення дослідницької діяльності, виникають труднощі з визначенням мети дослідження та пошуком оптимальних шляхів ऑiі досягнення, бракує навичок самостійної роботи над пошуком та обробкою необхідної інформації, практичних умінь проводити експериментальну частину дослідження, умінь представляти результати власної дослідницької діяльності.

Проведений етап дослідження дозволив здійснити кількісну та якісну характеристику сформованості дослідницької компетентності майбутніх товарознавців-експертів за визначеними критеріями та показниками. Аналіз експериментальних даних показав, що в процесі фахової підготовки майбутніх товарознавців-експертів існують протиріччя між спрямованістю майбутніх фахівців на дослідницьку діяльність та низьким рівнем їх мотивації, теоретичної та практичної підготовки. Аналіз результатів вказує на необхідність ціленаправленої підготовки майбутніх товарознавців-експертів до дослідницької діяльності, що сприятиме поетапному та послідовному формуванню у майбутніх фахівців дослідницької компетентності.

\section{REFERENCES}

1. Ильин Е. П. Мотивация и мотивы / Е. П. Ильин. - СПб.: Питер, 2000. - 512 с.

2. Карпов А. В. Рефлексивность как психическое свойство и методика ее диагностики / А. В. Карпов // Психологический Журнал. - 2003. - № 5. - С. 45 - 57.

3. Одегов Ю. Г., Руденко Г. Г., Апенько С. М., Мерко А. І. МОТИВАЦІЯ ПЕРСОНАЛУ: Навчальний посібник. Практичні завдання (практикум). - М.: Видавництво «Альфа-Прес». - 640 с., 2010

4. Усова А. В. Условия успешного формирования у учащихся научных понятий / А. В. Усова // Наука и школа. - М.: МПГУ, 2006. - № 4. - С. 57 - 59. 